\title{
The Challenges of Accounting Standards in Intellectual Property's Reporting, an Albanian Approach
}

\author{
Phd. Candidate Marsel Sulanjaku \\ Lecturer at "A.Xhuvani" University, Faculty of Economic, Faculty of Economic, Elbasan \\ msulanjaku@gmail.com
}

\section{Doi:10.5901/jesr.2014.v4n4p442}

\begin{abstract}
Intellectual property has become a key factor in measuring the business performance and its market value. Although the valuation and reporting of intellectual property is important for all companies, it is more crucial, especially to the intellectual property high intensively companies. Accounting standards were created keeping in focus the tangible assets, and despite the efforts and changes that are made, still they need revisions to track successfully the intangible assets. The rigid structure of accounting standards does not allow them to be more flexible in tracking and reporting the intangible assets in a new environment where most of businesses have in their financial table's components of intangible assets like intellectual property. We will briefly discuss some details regarding the treatment that international accounting standards like IAS 38 and FAS 142 reserve to the intangible assets and especially the intellectual property. Aside with our opinion, we will expose some of the well known researches and academics point of view, to suggest a fair disclosure and to give new insights in intellectual property reporting. The purpose of the research is to establish the inadequacy of the accounting standards in intellectual property reporting and to give new insights and advises regarding the discussed topics to overpass these inadequacies. The methodology used in the preparation of this paper will be that of the utilizing the foreign and national literature, and the utilization of the questionnaires and interviews with the certified accountants and the finance departments of selected businesses in Albania.
\end{abstract}

Keywords: Intellectual property, IAS 38 , accounting standard inadequacy, fair disclosure.

\section{Introduction}

Valuation and reporting of the intellectual property in today's modern economy has become a very discussed topic among the business entrepreneurs, academics and researchers from different areas. The intense research of intellectual property is related to the strategic competitive advantage that these assets can provide to the company, resulting in increasing performance and their market value.

Today, there is a general shift of investments from tangible to intangible assets, because of the competitive advantages and earning power that these assets can provide. In our modern global economy value creation takes place through innovation, knowledge, relationships and trademarks. If we observe the most successful companies worldwide we can see that they are based either on knowledge and innovation or they have based their investments and success in intangible assets.

Even despite the fact that intangible assets and intellectual property has a crucial role in company's performance and it's market value the traditional accounting systems are inadequate to measure and report the value of these assets. The abstract nature of these assets and the lack of the physical form leads to subjective treatment in their definition, recognition and valuation. ${ }^{1}$

The researchers of the field have not reach to a common definition or classification of intangible assets, but for the intellectual property there has been made more progress in their definition and their classification. That is because of the fact that intellectual property is more "tangible" compared to the other intangible asset. Intangible assets generally are accepted to be composed of two main components, human capital and structural capital . Structural capital is composed of two main components, external and internal structural capital. Intellectual property is part of external structural capital and in comparison with other intangible assets, intellectual property can be registered as such in the respective institutions and be protected by law. Intellectual property create strategic advantage by creating barriers to the third parties to use the specified intellectual property without the permission of the organization that posses it. Some types of intellectual property are :patents, trademarks, copyrights ,broadcasting rights, trade secrets, know how, licensing

\footnotetext{
1 Getting a Grip on Accounting and Intellectual Property.By Roya Ghafele, Associate Economic Officer, Intellectual Property and Economic Development Department, WIPO
} 
agreements, franchising agreements etc.

Even that intellectual property compared with other intangible assets is protected by law and registered in related institutions, the accounting standards do not consider them differently from other intangible assets and treat them under the same category. For this purpose we will use the term intangible assets when considering the accounting standards and will specify differently the intellectual property when we think it should be considered differently from other intangibles.

\section{The Gaps of Accounting Standards in Intellectual Property Disclosure}

Accounting system was first created in the beginning of XV.th century, and then developed in an environment where the main categories of a product's cost where material costs, labor costs and other overhead costs. In today's economic environment we observe that businesses are investing in new directions such as R\&D, brand names, patents, copy rights, know how, distributions channels etc. In intellectual property high intensively companies operating in sectors such as entertainment and media, software development and pharmaceutical sectors the traditional cost indicators are not the main cost of the product, but expenditures like R\&D, advertisement, investment in skilled labor are main cost of the products. In most of the cases investments in such sectors are not classified as such, but as expenditures . ${ }^{2}$ Based in these kind of businesses one can ask: How will the accounting standard evaluate the products' cost of these companies and the value of the whole company itself ?!

In this section we will discuss some of the "weak points" of accounting standards in the treatment of intangible assets and the intellectual property. As the accounting standards do not make a clear distinction of intellectual property and consider this element inseparably from intangible assets, we will use the general term "intangible assets" when referring to accounting standards and when needed we will consider the "intellectual property" differently. The effects of the accounting standards in financial statements and the inconsistencies between the financial perspective and real situation will be another element that we will consider in parallel with the discussed topics.

\subsection{The rising conflicts in accounting principles}

From the creation of the accounting system the accounting standards have made much progress in its development and adoption to the new market and economic conditions, that is because it is based in some general principles, where in focus of them is the user of these financial statements. According to a survey based on the interviews made to high level management of most success companies worldwide, they listed, according to their importance, the following information as the most important information they need to know related with the company they manage: ${ }^{3}$

- Information regarding the consummators or clients preferences or needs

- Information regarding the trademark and the reputation

- Financial projections regarding the future

- Information regarding the efficiency of R\&D projects

- Information regarding the supplier network chain

The actual accounting system cannot provide the in their financial statements information regarding the investment made in intangible assets as well as the basic information that managers require as listed above. The information regarding the above listed management priorities cannot be disclosed in financial statements because the difficulty that these information have to be "translated" in monetary base. The obstacle that accounting has in translating performance indicators in monetary based information makes the financial statements not sufficient for decision makers. The insufficient information regarding the company performance can be in conflict with the "full disclosure" principle.

We have the same situation regarding the intangible asset reporting on financial statements. Based on accounting standards (IAS 38 , FAS 141 \& FAS 142) an intangible asset can be recognized as an asset if and only if it fulfills all the following conditions 4 :

- The intellectual property should contribute directly or indirectly to future net cash inflows

- The entity should control this intangible asset or prevent others' access to it

\footnotetext{
${ }^{2}$ Goldfinger, C. 1997, Understanding and measuring the intangible economy: Current status and suggestions for future research. CIRET seminar. Helsinki.

3 "2th Annual Global CEO Survey-What Matters to CEOS in 2009?"PricewaterhouseCoopers, available at http://www.pwc.co.uk/eng/issues/ceomatters.html.

${ }^{4}$ http://www. ifrs.org/
} 
- It's cost should be measured in a reliable way

In practice it is difficult for an intangible asset to fulfill all of the above requirements. For example a brand name if it is internally generated can be generated through intense years of advertising, effective distribution channels or superior quality to obtain the customers trust. For a company it is difficult to trace all these expenses and to capitalize them as the cost of the brand name. Even through you might have an idea that these expenses would be considered later as the brand name's cost, you cannot capitalize them because you cannot be sure when this brand name can be created and whether it should generate future net cash inflows.

Even the fact that the accounting standards cannot recognize the internally generated intangible assets or other assets that do not fulfill the above requirements, it is obvious that these intangible assets like brand name, trade secrets, know how or patents exist and generate considerable cash inflows for their economic unit. Being conscious that even these intangible create much value to their company why do the accounting standards still not adapt to disclosure these intangible assets?!

The situation is the conflict between the accounting principles, where the accounting statements are required to be reliable to the users, that is , the information reported in these statement should be objective and based on transactions that have occurred or are reported that will happen for sure in the future. In the economic treatment of intangible assets we do not have that accuracy or objectivity regarding the possible cost of the intangible asset it's future economic cash inflows that can reliably evaluate its value.

On the other point of view, despite that we cannot measure in a reliable form the cost or future economic cash inflows, the managers and the third parties are conscious that they have a success because of a certain intangible asset or intellectual property that the economic unit might have. In this case even that a intangible asset exist and create value to the economic unit the potential investors cannot "see" this valuable asset in the financial statements, distorting the financial statements but not valuing accordingly the economic unit. The distortion of financial statements or the "hiding" of the intangible assets that generate cash inflows or that can create strategic advantage can prevent this economic unit from potential investments. In this situation we can ask which of the accounting principle is more important the "objectivity" or the "reliability"?! According to a research it is suggested that there is a positive correlation between the efficiency of the capital markets and the information regarding the intangible assets disclosed in the annexes of the financial tables, even that this information may not be based on "objectivity" principle provided by the standards. ${ }^{5}$

It seems that these principles are in a continuous conflict especially in intangible asset treatment because the emphases on the reliability principle can make the financial statements more subjective, trying to report an intangible that although might exist and has concrete earning power, it might not fulfill the other standards requirements causing the loss of the financial statements' objectiveness and on other hand being "objective" by not including the intangibles that have value and earning power for the company we practically "hide" these assets, and as a result the financial statements can lose their reliability.

\subsection{Lack of a common framework for Intellectual property valuation}

An economic unit should provide a detailed information related to intangible assets bought or internally developed by the unit, in relation to main classifications where it classify these assets. This information should include useful information such as their useful lives, depreciation policies that the company has chosen and the policies that will be used in the statement of financial statements. The financial statements should be able to give useful information regarding the depreciation expenses, different revaluation methods committed and other related information regarding these intangibles.

Even though many valuation and measurement models of intangible assets and intellectual property have been developed we still have lack of a common work frame in measurement and valuation of these assets. There exist different models regarding the measurement and valuation of intangibles. These models are divided in two main categories: monetary models and non monetary models. Financial accounting prefers to use the monetary models, because these models take in consideration only monetary values, while the non monetary models takes in consideration other performance factors that can not be expresses in monetary value like customer royalty, brand name recognition , future expectations etc. The most used monetary models are : market to book value, "Q" of Tobin for the intangible assets, Value added intellectual coefficient, Sullivan method for intangible asset valuation, economic value added model etc. Although there is a considerable number of monetary models, the accounting standards, IAS 38 , uses only the cost model and the revaluation model for intangible asset measurement and valuation. This is a very restrictive way in

${ }^{5}$ Barth, M. E., Clinch, G. and Shibano, T., 2003, Market effects of recognition and disclosure, Journal of Accounting Research 
intangible asset valuation that does not permit the valuation of intangible assets that are generated within economic unit, but it only takes in consideration the valuation of an intangible asset that is acquired separately or with a business combination. As a result the revaluation model can not be used in intangible assets that has not been initially valuated with the cost model, by not taking in consideration the intangible assets that exist and can have a significant contribution to the economic unit, but that is not obtained through a transaction in the past through separate acquisition or as a part of a business combination. The information regarding the valuation and measurement of intellectual property is heterogeneous and the accounting standards are very selective in using these models. In the actual situation where various models fail to converge into a common framework regarding the measurement and valuation of intellectual property accounting standards remain rigid and are not able to report the intangible assets.

\subsection{The "lost" of investments on intangibles, in general expenditures}

As a result of the accounting system not to track successfully the intangible assets the real investments made on intangibles despite the fact that are recognized or capitalized they also contribute in decreasing the financial performance. The investments on intangibles that are not recognized by accounting system are categorized as expenditures affecting negatively the earning performance of the economic unit.

Below we have listed some of the expenses required for creating and adding value to intangible assets, and that in fact very few of them are recognized by the accounting standards as investments in intellectual property and therefore not capitalized, such as costs associated with the acquisition, licensing or legal protection , patents , trademark and copyright ,investments in marketing campaigns and brands, acquisition of customer lists, manufacturing or quality certificate etc.

The treatment of different investment on intangible assets by accounting standards as expenditures results in discouraging the managers to invest in intangibles and intellectual property. If an economic unit is not encouraged to invest in intangibles it will lose its earning power as well as the strategic advantage in long term. On the other side the "hiding" of intangibles in general expenditures, contributes in the asymmetry of information. ${ }^{6}$ The asymmetry of information consists in spreading the financial information regarding an economic unit in a not fair way. That is the big investors who have the rights founds or connections can have a detail information regarding the investments made in intangibles that normally is "hidden" in general expenses, and on the other side the other not privileged potential investors cannot get a detailed information about the possible investments that the company might have undertake. ${ }^{7}$

\section{4 "Agency conflict" in intangible's investments}

Agency conflict is a well known term, and is used to describe where the interests of management is to show good performance indicators in short term that can be in conflict with shareholders' interests in long term. The lack of accounting standards reporting of internally generated intangible assets can lead to an agency conflict. It is almost accepted that the investments in intangible assets and intellectual property creates a strategic advantages towards other competitors as well as creating value for the company in a long run. The lack of recognition by the accounting standards of investments made for internally generated intangibles classify these investments as expenses, results in a decrease in earnings performance of the company. Thus the management is discouraged to invest in intangibles and intellectual property because these investment would contribute to lower the earning performance in financial statements. On the other hand the shareholders are interested in investing in intangibles in order to create value or strategic competiveness in the future.

\subsection{High volatility of companies' value in possession of intellectual properties}

The internally generated intangible assets are very difficult to be recognized by accounting standards, mainly because the cost of internally generated intangibles is difficult to be measured appropriately and the difficulties in demonstration the future cash inflows. Because of these restrictions mostly of internally generated intangibles are not recognized in the financial statements even when the company has registered them in intellectual property protection offices .The international accounting rules are the same but there exist different approaches and adoptions of these standards regarding the intangibles in different countries. Below have classified the different treatment of internally generated

\footnotetext{
${ }^{6}$ Aboody, D. and Lev, B., 2000, Information Asymmetry, R\&D and Insider Gains, Journal of Finance, LV

7 Jensen, M. and W. Meckling [1976], The theory of the firm: managerial behavior, agency costs and ownership structure. Journal of Financial Economics, n. 3
} 
intangibles by different countries:

Table 1.

\begin{tabular}{|c|l|l|l|}
\hline & \multicolumn{1}{|c|}{$\begin{array}{c}\text { Non recognition or very } \\
\text { restrictive recognition. }\end{array}$} & $\begin{array}{c}\text { Recognition with short time } \\
\text { amortization periods }\end{array}$ & \multicolumn{1}{|c|}{$\begin{array}{c}\text { Voluntary recognitions } \\
\text { according to accounting } \\
\text { standards }\end{array}$} \\
\hline & $\begin{array}{l}\text { U.S.A } \\
\text { England }\end{array}$ & & France \\
Canada & Internally generated \\
Intagible assets & China & Holland & Belgium \\
& Denmark & Saudi Arabia & Bulgaria \\
& Germany & & Australia \\
& Norway & & New Zeeland \\
India & & \\
\hline
\end{tabular}

Source: Healy P. M., Myers S., Hoëe C. D., "Journal of Accounting Research" 2002, Vol. 40,

The failure to recognize these assets in balance sheet, results in very distorting situation in case of company acquisitions or if the company decides to sell an intellectual property. In these case the acquisition price of the company can be much higher then it's accounting value which leads to a distortion of the users of financial statements which makes the users of these financial statements to be skeptic weather the financial accounting system can really measure a company's value.

In the case of a simple intellectual property selling / buying procedure we have two asymmetric situations where the seller of this intellectual property appears to have incomes out of nothing, and this situation can be paradoxical in case of high valuable intellectual properties. On the other hand the buyer of this intellectual property can register in its financial statements, based on the buying price which in this case is market value.

In this specific point we have an asymmetry in treatment of the parties dealing in intellectual property acquirements by accounting standards. ${ }^{8}$ The economic unit which holds this cannot report this intellectual property even it can be valuable but the buyer in the same moment can report this intellectual property based on the buying transaction. In this specific time the selling company, seems that is making money out of nothing, and the buyer is seen as it is buying a normal, tangible asset.

\section{Analysis of the Survey}

In the previous session we discussed some of the inconsistencies in regard of the accounting treatment of intangibles and the gaps that accounting standards create between the financial and the real situation of an economic entity.

In this session we will examine the main issues mentioned above, in regard of the Albanian certified public accountants point of view and companies managers' that have intellectual property assets in their financial statements.

The data used in the survey is gathered mainly by questionnaires and interviews distributed to Albanian certified public accountants and the managers that have intellectual property assets in their financial statements. ${ }^{9}$

Asked about the conflicts between "objectivity" and "reliability" principles, the Albanian accountants prefer to be objective rather than reliable. This is because the Albanian market is still not open to the new investors because the stock exchange is not yet opened. For this reason the managers of the companies that deal with intellectual property are not focused to disclose the real value of the intellectual property to attract new investors rather than to disclose it strictly according to the accounting standards avoiding any possible penalty from the tax office. For this reason $86 \%$ of the replies of the questionnaires were that that Albanian CPAs prefer to be strict in the accounting regulation appliance.

Asked about a lack of common framework for IP valuation , 75\% of the replied questionnaires reported that the management is shifting from the usage of the monetary models in the usage of non-monetary models .Monetary models generally are based in the idea of the comparison of the earnings ratios like ROI. ROE and other ratios with similar companies or sectors average ratios, and the surplus difference is then calculated and finally treated as the value of the intangibles. Monetary models are not preferred because in Albania there is an absence in the official statistics like sector's earning capacity ROE, ROI and other companies earning indicators resulting in a non comparison between the

${ }^{8}$ Lev, B. (2001) Intangibles: management, measurement and reporting Washington, DC: The Brookings Institution

${ }^{9}$ The responded rate of questionnaires were relatively limited in number mostly due to the time limitation . 
studied company and the similar companies .Instead, the managers are focused in using non-monetary models because they take in consideration more factors, rather than just the monetary factors and serve as a strategic tool to evaluate the company value creation in the future.

Asked about the "lost" of investments on intangibles, in the general expenditures $84 \%$ of the accountants and managers agree that the actual accounting standards do not distinguish the investments made in intangibles and report them as general expenses. They are conscious that accounting standards should be more flexible in the treatment of the investments made in intangibles, by adopting new rules in the recognition of these investments.

In regard of agency conflict and the high volatility in companies value that have an intellectual property , $80 \%$ of the CPAs understand the problem theoretically but are not concretely conscious of these conflict due to the lack of the big enterprises in Albania, and where most of the companies decisions are influenced directly from the owner. In this circumstances we are at an early stage to discuss the agenda's conflict.

\section{Conclusions}

The fair valuation and reporting of the intangibles and specially the intellectual property is one of the most discussed topics among the accountants as well as the managers that are involved in companies that posse's intellectual property. The reason is the rising of the investments from companies in the new, global economy in these assets and on the other side the abstract nature of these assets leads to subjective conclusions among the accounting professionals.

As in the developed countries the investments and importance of intellectual property is raising day by day even for the Albanian companies and the business concepts. The Albanian accountants aware of the importance of the intangibles and the debates among professionals and academics in the field of accounting are being part of this debate, in accordance of the problematic that the Albanian economy and the business practice that they are facing. ${ }^{10}$ In this respect they are becoming aware of the inadequacy of accounting standards in treatment of intellectual property, and they are being organized in giving suggestions in the improvement of the accounting standards, as the intellectual property now is a common asset that they face in most of the financial statements of the Albanian companies.

From our research, based on the questionnaires and interviews made with Albanian CPAs and managers, regarding the most discussed topics related to intangibles and intellectual property in particular, we can state that one of the biggest obstacles in intangibles reporting is, like other developed countries, the valuation of the intangibles. As the valuation models of intangible assets still do not converge in a similar framework the accounting standards cannot rely on them to report the intellectual property value. This situation implies the need to encourage voluntary reporting of intangible assets within the framework defined by current accounting models in financial statements notes.

In our opinion, in this situation the accounting standards should encourage the voluntary reporting of intangible assets and intellectual property in their financial statements notes, in order to provide a more complete and reliable information about the investments and the value of these "hidden" assets. Although, based on the specific economical situation of Albania where the informality do not motivate the business owners and managers to disclose the real value of the companies and on the other side the lack of a stock exchange makes almost impossible the usage of monetary accounting models to measure and evaluate the intellectual property properly, even for the companies that are interested in reporting their intellectual property the Albanian accountants and managers aware of the importance that the intangibles are gaining are becoming more interested in this topic. In this regard they are being involved in the debate for a fair disclosure and reporting of intangibles. For the Albanian economic situation, issues like agency conflict and high volatility are still not "tangible" because of the lack of big enterprises and the stock exchange.

Issues like the "hiding" of investments made for intangibles in general expenses and a common framework for intangible valuation are involving each day more the Albanian accountants and managers in the debate for an improvement of the accounting standards in this direction. In this respect we can state that the Albanian accountants will be soon an active part of the debates regarding the improvement of the accounting standards in intellectual property disclosure and reporting.

\footnotetext{
${ }^{10}$ Sulanjaku, M. (2013). Accounting and Auditing of Intellectual Property in Albania. Academic Journal of Interdisciplinary Studies, 2(9), 400 .
} 


\section{References}

Aboody, D. and Lev, B., 2000, Information Asymmetry, R\&D and Insider Gains, Journal of Finance, LV

Barth, M. E., Clinch, G. and Shibano, T., 2003, Market effects of recognition and disclosure, Journal of Accounting Research http://www.ifrs.org/

Getting a Grip on Accounting and Intellectual Property.By Roya Ghafele, Associate Economic Officer, Intellectual Property and Economic Development Department, WIPO

Goldfinger, C. 1997, Understanding and measuring the intangible economy: Current status and suggestions for future research. CIRET seminar. Helsinki.

Jensen, M. and W. Meckling [1976], The theory of the firm: managerial behavior, agency costs and ownership structure. Journal of Financial Economics, n. 3

Lev, B. (2001) Intangibles: management, measurement and reporting Washington, DC: The Brookings Institution

Sulanjaku, M. (2013). Accounting and Auditing of Intellectual Property in Albania. Academic Journal of Interdisciplinary Studies, 2(9), 400.

2th Annual Global CEO Survey-What Matters to CEOs in 2009?"PricewaterhouseCoopers, available at http://www.pwc.co.uk leng/issues/ceomatters.html. 